\title{
A Study of the Cultivation of Innovative Talents Based on Subject Competition Concerning Majors of Economics and Management
}

\author{
Sun Cuiyan \\ National Demonstration Center for Experimental Economics and Management Education(Guangxi Universit \\ y of Finance and Economics), Daxuexi Road NO.189, Nanning, Guangxi, China
}

\section{7@qq.com}

Keywords: subject competition; innovative talents; majors of economics and management; specific suggestions.

\begin{abstract}
Nowadays, there is an increasingly closer relationship between economic society and higher education. Cultivating innovative talents becomes an urgent and important target of current higher education with the purpose to meet the demands of our rapidly developed society. Organizing subject competition is an indispensable approach applied by colleges to cultivate students with strong innovative consciousness and innovative ability. This essay discusses the relationship between subject competition and innovative talents by defining the two, and further to put up with some specific suggestions in consideration of current situation with regard to subject competition for majors of economics and management so as to better improve the positive functions of the former acting on the latter.
\end{abstract}

\section{Introduction}

Innovative ideas, such as knowledge innovation, technology innovation, mass innovation, etc., have gradually caught the attention of an increasing number of scholars and researchers, following up the pace of the development of our society. However, all kinds of innovation are dependent on the cultivation of innovative talents. Just as our President Xi Jinping once pointed out in 2004 that we must occupy the leading position of the world in terms of technology innovation; we must identify talents through innovation practice, cultivate talents during innovation activities, and gather talents together in the career of innovation; we must spare no effort to cultivate innovative and technological talents with large scale, reasonable structure and high quality [1]. College students are the main source of technological talents of our country, making them undoubtedly the main targets of the cultivation of innovative talents. As the fostering bases of innovative talents [2], colleges, obviously, shoulder the urgent task of strengthening innovation education and cultivating innovative students.

Being an important and indispensable approach applied by a variety of colleges to cultivate innovative students, subject competitions do help a lot while there still leave us with some points that need to be improved.

\section{Subject Competition}

\subsection{Definition of Subject Competition.}

Subject competition refers to a series of activities aiming to cultivate students' learning interests, enhance their confidence in and initiative of learning and research, develop their sense of teamwork and improve their comprehensive ability during the process of finding and solving problems through the way of competitions which can arouse students' motivation to make practice under the guidance of related knowledge they have learned and conduct independent exploration based on the combination of classroom teaching and integrated application of professional knowledge [3,4].

\subsection{Type of Subject Competition.}

The type of subject competition varies while being classified with different criteria. When classified by organizing department, it can be categorized into the following four, i.e., A, B, C and D, 
wherein A represents subject competition organized by the Ministry of Education of the People's Republic of China, B by the Department of Education of each province, C by the Advisory board under the Ministry of Education and D by various enterprises. According to the level of competition, they can be divided into international, national, provincial, municipal and school level, respectively. The above two kinds of classification are the most common ones. In addition, subject competition can also be divided into different types on the basis of the frequency, the content and the number of participants and so forth.

\section{Subject Competition and the Cultivation of Innovative Talents}

\subsection{Innovative talents.}

Innovative talents refer to people who can discover new phenomena and laws, come up with new theories and methods, create new material products and ideological and cultural achievements, and solve problems having not been solved before by the application of knowledge acquired and the observation, analysis, integration and evaluation of objective items. In other words, they are such a group of people who are endowed with innovative consciousness, spirit, thinking and ability, with which they can make innovative achievements.

\subsection{The Role of Subject Competition in the Cultivation of Innovative Talents}

\subsubsection{Cultivating Innovative Consciousness and Innovative Spirit.}

Innovative consciousness means the intention or motivation to create new things in accordance with the requirements of our society and individual development. Actually, each person, college students included, of course, has innovative consciousness in his or her deep heart. Therefore, we only need to create an appropriate opportunity that will help to arouse it up. Since students participating in subject competition will with no doubt try their best to win the competition, their innovative consciousness will be thus aroused to help them.

As for innovative spirit, it shows us a mental attitude encouraging form a new mind or thing, which obviously cannot be taught merely in classroom by college teachers. Irrespective of form or content, subject competition is innovation-inclusive, strongly encouraging college students to cooperate with those who are majoring in different subjects. It will help college students to maintain a good innovative spirit.

\subsubsection{Cultivating Innovative Thinking and Innovative Ability.}

Innovative thinking is a kind of thinking style that cannot be formed into through passive acceptance of basic knowledge from books. Only when such kind of knowledge learned is applied into practice and verified through various kinds of methods, such as collaborating with team members, consulting the instructor and repeated practice and so on, can students gradually equip themselves with innovative thinking.

Additionally, subject competition asks for students to turn their innovative thinking into actual works, where students' innovative ability will be greatly trained as well. As for innovative spirit, it shows us a mental attitude encouraging students to form a new mind or thing, which obviously cannot be taught merely in classroom by teachers. Irrespective of its form or content, subject competition is innovation-inclusive, strongly encouraging college students to cooperate with those who are majoring in different subjects. It will help college students to maintain a good innovative spirit. [5]

\subsubsection{Cultivating Ability of Social Adaptation.}

Judges invited for various kinds of subject competition are often entrepreneurs and venture capital specialists. Their opinions or suggestions given to students will help them to have a better understanding of the real needs of our society. Furthermore, some judges will even make investment without hesitation as long as the idea brought forth by students are innovative and feasible enough. Even though students fail the competition, they will move on forward on a right direction, saving 
them much more energy.

\section{Issues of Subject Competition for Majors of Economics and Management}

\subsection{Too Many Types with Different Quality.}

There is a wide variety of categories of subject competition for majors of economics and management at home and abroad both officially and non-officially. Some colleges organized subject competition as many as possible, aiming to cultivate much more innovative students. However, the result is contrary for that the energy of students are limited, which only allows them to participate in some competitions rather than all. When colleges organize such kind of competitions without any careful and reasonable evaluation, a proportion of students will surely be deeply frustrated and gradually have no interests because of competitions with low quality and relevance. Thus, whether colleges can reasonably select competitions that meet the requirements of the cultivation of students' innovative ability or not becomes with no doubt an problem that cannot be ignored or underestimated.

\subsection{Weak Initiative Consciousness of Students.}

Innovation education is mainly implemented since college, leaving students a feel that it is of less importance. By weighing the importance of their examination results and that of the competition, some college students would rather spend more time on their study and other activities that will have great effects on their graduation instead. To make it worse, some colleges force students to participate in such competitions, greatly reducing students’ enthusiasm and initiative.

\subsection{Limited Time of Teachers.}

Different from teachers in primary and secondary school, college teachers have less time to stay with students. They have no office in the campus, so college students often can no longer stay with their teachers after class. Furthermore, college teachers shoulder great pressure of both teaching and research with regard to their professional title promotion. Even when they are willing to spare the time to give some guidance, they will choose those who are excellent in their class and stop giving advice as soon as possible when the competition ends and students then cannot make more in-depth research. Consequently, the process of the cultivation will be then disrupted badly.

\section{Specific suggestions to Cultivate Innovative Talents Based on Subject Competition for Majors of Economics and Management}

\subsection{Combining Subject Competition with Daily Teaching Tightly.}

Teaching is the main task, as well as responsibility and obligation of college teachers. When teachers integrate some contents concerning subject competition into their daily teaching, they will first have to search for a better way to make those two combined closely. And this is also an effective method to evaluate whether the competition conforms to the college's target of the cultivation of innovative talents. Consequently, subject competition that does not match the target of the cultivation of innovative talents for this major will be deleted from the list, while those that is consistent with the target will be enhanced through various efforts. By this method, it will inspire students to think actively, broaden students' horizon, improve students' ability to analyze and solve problems, and stimulate students' enthusiasm and initiative.

\subsection{Developing a Correct Understanding of Subject Competition.}

Colleges should make more effort to increase the variety of propaganda methods so as to create an innovative atmosphere on campus from the very beginning when students are at the first year of college life, for example, interpreting relevant policies, setting good examples, organizing experience sharing meetings, posting inspirational sayings, etc. 


\subsection{Establishing Necessary and Suitable Incentive Mechanism.}

On the one hand, the scope of rewards for students should be as wide and diversified as possible, making each students have the chance to participate in and enjoy rewards. On the other hand, teachers who follow up the project give their advice and suggestions should also be rewarded in various ways. Only when both students and teachers devote themselves totally into it, subject competition will possibly play its positive role to the limit.

\section{Conclusions}

To sum up, subject competition, as an indispensable method, is an important part of the cultivation of innovative talents for colleges. However, attentions should be paid to the fact that subject competition cannot be treated as the mere way to cultivate innovative talents. All positive functions it has will be effective only when it is consistent with the nature of teaching. Colleges should try to create appropriate environment that is in favor of inducing students to participate in appropriate subject competition at suitable time and with suitable requirements, thus helping students become innovative talents step by step.

\section{References}

[1] Information on http://www.cpc.people.com.cn

[2] Xueying Tian: BTAIJ. 10(8)(2014), p. 2514-2519

[3] Guofeng Li, Shiying Zhang, Bin Li: Experimental Technology and Management. 3(2013), p.24-26 (In Chinese)

[4] Juxia Wang: Education Teaching Forum. 48 (2017), p. 193-195 (In Chinese)

[5] Yan Guo: Education Teaching Forum. 6 (2016), p. 225-226 (In Chinese) 